\title{
Covid-19 Pandemi Dönemindeki Uzaktan Eğitim Sürecinde Fen Bilgisi Öğretmenlerinin Mesleki Kazanımlarının ve Sorunlarının İncelenmesi
}

\author{
Hasan BAKIRCI \\ Van Yüzüncü Y11 Üniversitesi, Eğitim Fakültesi \\ hasanbakirci09@gmail.com \\ ORCID ID: 0000-0002-7142-5271 \\ Nurgül DOĞDU \\ Van Yüzüncü Yıl Üniversitesi, Eğitim Bilimler Enstitüsü \\ nurguldogdu13@gmail.com \\ ORCID ID: 0000-0002-5772-0338 \\ Hüseyin ARTUN \\ Van Yüzüncü Yıl Üniversitesi, Eğitim Fakültesi \\ huseyinartun@gmail.com \\ ORCID ID: 0000-0002-8496-918X
}

\begin{tabular}{lrr} 
Araştırma Makalesi & DOI: $10.31592 /$ aeusbed.909184 \\
\hline Geliş Tarihi: 03.04.2021 & Revize Tarihi: 31.05.2021 & Kabul Tarihi: 17.05.2021
\end{tabular}

\section{Atıf Bilgisi}

Bakırc1, H., Doğdu, N. ve Artun, H. (2021). Covid-19 Pandemi dönemindeki uzaktan eğitim sürecinde fen bilgisi öğretmenlerinin mesleki kazanımlarının ve sorunlarının incelenmesi. Ahi Evran Üniversitesi Sosyal Bilimler Enstitüsü Dergisi, 7 (2), 640-658.

ÖZ

Koronavirüs (Covid-19) pandemisi, dünya ülkelerini olduğu gibi ülkemizi de birçok alanda etkilemiştir. Etkilenen bu alanların başında eğitim kurumları gelmektedir. Bütün ülkelerde olduğu gibi ülkemizde de pandeminin etkisiyle eğitim-öğretim faaliyetleri uzaktan eğitim ile yürütülmeye çalışılmıştır. Bu araştırmanın amac1, Covid-19 pandemi döneminde uzaktan eğitim sürecinde Fen Bilgisi öğretmenlerinin mesleki kazanımlarının ve sorunlarının incelenmesidir. Bu amacı gerçekleştirmek için araştırmada, nitel araştırma yöntemlerinden olgu bilim (fenomenoloji) deseni kullanılmıştır. Araştırma, Doğu Anadolu Bölgesinde bir ilde görev yapan 10 Fen Bilgisi öğretmeni ile yürütülmüştür. Katılımcıların belirlenmesinde kolay ulaşılabilir örneklem yöntemi kullanılmıştır. Verilerin toplanmasında araştırmacılar tarafından geliştirilen yarı yapılandırılmış mülakat formu kullanılmıştır. Pandemi nedeniyle öğretmenler ile mülakatlar "Zoom" programı üzerinden gerçekleştirilmiştir. Veriler, betimsel ve içerik analiz yöntemi ile çözümlenmiştir. Fen Bilgisi öğretmenleri, Covid-19 pandemi sürecinde yapılan uzaktan eğitim uygulamalarının yaklaşımının mesleki gelişimlerine katkı sağladığını belirtmişlerdir. Öğretmenler, özellikle birçok bilgisayar programını, yazılımını ve donanımını etkili bir şekilde kullanmayı öğrendiklerini ifade etmişlerdir. Buna karşın öğretmenler, uzaktan eğitim sürecinde öğretmen ve öğrenci olmak üzere iki temel sorun ile karşılaştıklarını dile getirmişlerdir. Öğrencilerin uzaktan eğitim sürecine katılma konusunda isteksiz oldukları ve öğrencilerin bilgisayara/internete erişmede sıkıntı yaşadıkları görülmüştür. Bu durum, öğrencilerin derse katılımlarını zorlaştırdığ̣ için öğrencilerde motivasyon düşüklüğüne neden olmuştur. Bu durumu azaltmak adına derslerin belli bir süreliğine uzaktan eğitim ile devam edeceği düşüncesi öğrencilere söylenmelidir. Her ne kadar ev ortamını sınıf ortamına benzetmeleri zor olsa da uzaktan eğitim sürecinin ciddiye alınarak sınıf ortamındaymış gibi derslere odaklanmaları gerektiği öğrencilerin yaşına uygun bir dille anlatılmalıdır.

Anahtar Kelimeler: Fen bilgisi öğretmeni, covid-19 pandemisi, uzaktan eğitim.

\section{Investigation of Professional Achievements and Problems of Science Teachers in the Distance Education Process of Covid-19 Pandemic Period}

\begin{abstract}
As much as any other country, the Covid-19 pandemic has also affected my sectors in our country too. Educational institutions are at the top of these affected areas. Like other countries, due to the affects of the pandemic, education-learning activities have been tried to be carried out by distance learning in our country as well. The purpose of this research is to investigate the problems and achievements of Science teacher during the distance education period of Covid-19 pandemic. In order to achieve this, in this research science (phenomenology) pattern has been used as one of the qualitative research methods. The research was conducted with 10 science teachers working in a city in the Eastern Anatolia Region. Easily accessible sampling method was used in determining the participants. Semi-constructed interview form was used by researchers in data gathering. Due to the pandemic, interviews with teacher were conducted through "Zoom". Data was resolved by narrative and content analysis method. Science teacher have stated that, distance education approach during the Covid-19 pandemic period has contributed to their occupational skills.
\end{abstract}


Teachers have stated that, they learned to use especially a lot of computer programmes, software and hardware. Despite to this, teachers also stated that, they encountered two fundamental problems as teachers and students during the distance education period. It has been evaluated that, teachers were insufficient when it came to using technological devices in distance education. It has been witnessed that, students were unwilling to participate in the distance education process and they also suffered hardships to acquire computer/internet access. As this situation made it hard for the students to participate in classes, it caused a low level of motivation in students. In order to reduce this situation, students should be told that the lessons will continue with distance education for a certain period of time. Although it is difficult to compare the home environment to the classroom environment, the need to take the distance education process seriously and focus on the lessons as if they were in the classroom should be explained in a language appropriate for the age of the students.

Keywords: Science teachers, covid-19 pandemic, distance education.

\section{Giriş}

Dünyanın varoluşundan günümüze kadar geçen süre zarfında, insanların birçok doğal afetle karşılaştığ1 söylenebilir. Günümüzde tüm dünyayı etkileyen Covid-19 pandemisi, insanların karşılaştığ 1 son doğal afetlerden birisidir. Bu doğal afet, bütün kıtalarda etkisini gösteren ve insanlığ1 rahatsız eden en önemli pandemilerden birisidir. Dünya Sağlı Örgütü (DSÖ), bir hastalığın pandemi olarak tanımlamasında belli ölçütleri dikkate almaktadır. Bu ölçütler, insandan insana rahatlıkla geçmesi ve devamlı bir biçimde bulaşabilmesi, mutasyona uğramış bir faktör olması, tüm ülkeleri tehdit eden bir hastalık olması ya da daha önceden görülmemiş bir virüs olması şeklinde açıklamıştır (Türkiye Bilimler Akademisi [TÜBA], 2020).

Covid-19 ismi; DSÖ tarafından "korona" için "CO", "virüs" için "VI", "hastallk" için ise "D" şeklinde açıklanmıştır. Covid-19 Çin'in Hubei eyaletine bağlı Wuhan kentinde 31 Aralık 2019 tarihinde tüm dünyaya yayılmaya başlamıştır. DSÖ, Covid-19'u 11 Mart 2020 tarihinde "pandemi olarak" ilan etmiştir (DSÖ, 2020). Bütün ülkelerde hızla yayılmakta olan Covıd-19 vaka sayısıyla birlikte toplumsal endişeler ve kaygılar da tüm ülkelerde artmaya başlamıştır (Lin, 2020). Aralık 2019'dan sonra; ekonomi, sağlık, sosyal faaliyetler ve eğitim alanında kritik değişiklikler meydana gelmiştir Eğitim kurumlarında ilk kez bu kadar büyük bir evrensel ölçekte etkilenme söz konusu olmuştur. Yeni tip Covid-19 salgınının yayılmasını kısıtlamak amacıyla dünyanın birçok ülkesinde tüm eğitim kademelerinde gerekli tedbirler alınmaya başlanmıştır. Tüm dünyada eğitim-öğretim faaliyetleri yaklaşık 1.58 milyar öğrenci için durma noktasına gelmiştir. Türkiye de birçok ülke gibi, bu pandemiden ciddi şekilde etkilenmiştir. Bundan dolayı eğitim kurumları, uzaktan eğitim yaklaşımını kullanmaya başlamıştır (Genç ve Gümrükçüoğlu, 2020).

Türkiye'de Milli Eğitim Bakanlığı 2019 raporuna göre 950 bin civarında öğretmen ve 18 milyon civarında öğrenci vardır (Milli Eğitim Bakanlığı [MEB], 2020). Milli Eğitim Bakanlığı örgün ve yaygın eğitim kurumlarının 16 Mart 2020 tarihinden itibaren kapatılmasıyla salgından etkilenen en büyük kamusal alan haline gelmiştir. Ekonomilerini korumakla ilgilenen devletlerin çoğu Covıd-19 salgınının oluşturduğu karışıklıktan dolayı eğitim sürecini devam ettirmek için dijital teknolojilerin kullanımını benimseyen acil durum önlem paketleri başlatmışlardır (Angoletto ve Queiroz, 2020; Lee, 2020). Türkiye'de uzaktan eğitim, Eğitim Bilişim Ağı (EBA) ve Türkiye Radyo Televizyon Kurumu Eğitim Bilişim Ağı Televizyon (TRT EBA TV) kanalları aracıllğıyla gerçekleştirilmiştir. Bu öğrenme sürecinde uzaktan eğitim ile ilgili bazı eksiklikler ortaya çıkmıştır. Milli Eğitim Bakanlığı tarafından bu eksikliklere hemen müdahale edilmiş ve bu sorunlar ivedilikle giderilmeye çalışılmıştır. Özellikle uzaktan eğitim sürecinde EBA'nın teknolojik ve öğretim materyalleri bakımında zenginleştirilmesinde Milli Eğitim Bakanlığı'nın önemli katkıları olmuştur (Doğan ve Koçak, 2020; Sarıtaş ve Kızkapan, 2020). Buradan hareketle pandeminin başlangıcında uzaktan eğitimde bazı sorunların olduğu ancak son dönemlerde bu sorunların minimum düzeye indirildiği söylenebilir. Dolayısıyla Milli Eğitim Bakanlı̆̆ı'nın pandemi sürecinde uzaktan eğitimin etkili gerçekleşmesinde önemli katkılarının olduğu anlaşılmaktadır.

Covid-19 pandemisi, Dünya'da yaklaşık bir buçuk milyar öğrencinin yüz yüze öğrenme ortamlarından uzaklaşmasına neden olmuştur. Ülkeler, pandeminin öğrenme ortamlar üzerindeki olumsuz etkilerini en aza indirgemek için uzaktan eğitim platformlarılla eğitimdeki bu zorunlu 
boşluğu doldurmaya çalışmışlardır. Karantina günleri ve eğitim kurumlarının kapatılması ile tüm dünya beklenmedik bir süreç içerisine girmiştir. Eğitimler evde dijital platformlardan desteklenmeye ve sürdürülmeye çalışılmıştır. Bu durum, doğal olarak uzaktan eğitimi ya da bir diğer adıyla çevrimiçi eğitimi gündeme getirmiştir (Genç ve Gümrükçüoğlu, 2020). Günümüzde örgün eğitime alternatif olarak doğan uzaktan eğitim mekân ve zaman sınırlaması olmaksızın içerisine teknolojinin de bütünleştirildiği bir eğitim öğretim sistemidir (Uşun, 2006; Yamamoto ve Altun, 2020). Birçok dil eğitimleri, mesleki ve kariyer sertifika programları, lise ve üniversite sisteminde uygulanan açık öğretim modeli ülkemizde yıllardır uzaktan eğitimin bir parçası olarak uygulanmaktadır. Türkiye bu bakımdan uzaktan eğitim sistemine yabancı değildir. Uzaktan eğitim alan öğrenci sayısı da her geçen gün artmaktadır. Belirli bölümler için devlet okullarında uygulanan uzaktan eğitim modeli giderek gelişen ve yaygınlaşan bir eğitim sistemidir. Uzaktan eğitim yaklaşımı, koronavirüs tedbirleri kapsamında çok daha geniş bir kullanım alanına sahip olmaya başlamıştır. Bu sistem öğrencilerin fiziki bir ortamda ders görmelerinin sakıncalı olabileceği gerekçesi ile klasik eğitim sunan ortaöğretim ve üniversitelerin tedbir amaçlı olarak uzaktan eğitimin daha da yayılmasını sağlamıştır (Genç ve Gümrükçüoğlu, 2020).

MEB'in diğer ülkelere kıyasla bu pandemi ile etkili mücadele ettiği görülmektedir. Bu konu da MEB öğrencilere farklı alternatifler sunmuştur. Bunlardan bir tanesi internet üzerinden öğrenci katılımını sağlayan platform bir diğeri ise televizyon üzerinden sunulan hizmetlerdir. Özellikle MEB tüm öğretim kademeleri için ders ile ilgili içerikler önceden hazırlanmış ve Eğitim Bilişim Ağı sistemine yüklenmiştir. MEB öğrencilere belirlenen saatlerde TRT EBA TV kanalları üzerinden belirli saatlerde her sınıf seviyesine uygun olarak dersler vermeye başlamıştır. EBA platformu üzerinden öğrencilere kendi öğretmenleri tarafından canlı ders uygulaması ile dersler oluşturulup verilmeye çalışılmıştır. İnternet ağına öğrencilerin erişimini sağlayabilmek için MEB, EBA destek noktaları ve gezici sınıflar gibi uygulamalara başvurmuştur. Mobil operatörler üzerinden tüm öğrencilere EBA'da geçerli belirli miktarda ücretsiz internet hizmeti sağlaya başlamıştır (MEB, 2020).

Milli Eğitim Bakanlığı, 2020-2021 eğitim-öğretim y1lının güz döneminde seyreltilmiş ve aşamalı eğitim ile hibrit eğitim sürecine başlamıştır. 6. ve 7. sınıflarda uzaktan eğitim; 5 . ve 8 . sınıflarda da yüz yüze eğitim yapılmaya başlanmıştır. Ders saatleri yüz yüze eğitim alan tüm sınıflarda bütün sınıflarda azaltılmıştır. Fen Bilimleri dersi de haftalık ders süresi 160 dakikadan 60 dakikaya indirilmiştir (MEB, 2020). Hibrit adını taşıyan eğitim modeli harmanlanmış öğrenme ve karma öğrenmeyi içerisine alan bir öğrenme şekli olarak tanımlanmaktadır. Yani bu model yüz yüze eğitim metodunun çevrimiçi eğitim materyalleriyle harmanlanması yoluyla zenginleştirilmesi olarak ifade edilebilir. Öğrencinin hibrit eğitimin çevrimiçi kısmında kendi eğitim hızını kendisinin belirleyebilmesi hibrit eğitimin en önemli avantajlarından biridir. Bazı çevrimiçi öğrenme yöntemleri, öğrenciler tarafından istenildiği kadar tekrar edilebilme ve istediği yerde duraklatılabilme özelliğine sahiptir (MEB, 2020). Bu çevrimiçi öğrenme yöntemlerine yönelik Covid-19 pandemi sürecinde birçok çalışmanın yapıldığı söylenebilir. Bu çalışmalardan bazılarına aşağıda yer verilmiştir.

Çakın ve Külekçi-Akyavuz (2020) öğretmenler ile bir çalışma yapmışlardır. Çalışmada katılımcılar, veliler ve öğrenciler ile iletişim sorunları yaşadıklarını belirtmişlerdir. Ayrıca öğrencileri motive etmek için destekleyici etkinlikler yaptıklarını, güzel sözler söylediklerini ve okulun devam ettiğini hissettirdiklerini belirtmişlerdir. Bayburtlu (2020) tarafından Türkçe öğretmenleri ile yapılan bir çalışmada öğretmenler, öğrencilerin bir kısmında tablet, bilgisayar gibi cihazların olmayışından canlı derslere katılamadıklarını, velilerin bir kısmının bu süreçte ilgisiz olduğunu ve öğrencilerini bilgisayar başındayken dersleri takip etmediklerini ifade etmişlerdir. Ayrıca öğrencilerin derslere katılım düzeylerinin istenilen seviyede olmadığını dile getirmişlerdir. Covid-19 pandemisinin pedagojik yansımalarının araştırıldığı bir çalışmada, toplum tarafından uzaktan ve yüz yüze eğitim hizmetlerinin öneminin arttı̆̆ 1 sonucuna ulaşılmıştır. Bununla birlikte uzaktan ve yüz yüze eğitimin hem niceliği hem de niteliğinin önemli olduğu ortaya çıkmıştır (Can, 2020). Külekçi-Akyavuz ve Çakın (2020), okul yöneticilerinin Covid-19 süreci kapsamında eğitim sistemi içerisinde birtakım sorunlar yaşadıklarını belirlemişlerdir. Bu sorunlar teknik olarak yetersizlik, bilgi eksikliği, iletişim eksikliği, öğretmenlerin ilgisizliği ve planlama yetersizliği olarak öne çıkmaktadır. Arslan ve Şumuer (2020) yapmış oldukları çalışmada, öğretmenlerin daha çok fiziksel düzen boyutu olan donanım, 
yazılım ve plan-program etkinlikleri öğretiminin değerlendirilmesinde sorun yaşadıklarını belirlemişlerdir. Duban ve Şen (2020), tarama modelinin kullanıldığ çalışmada sınıf öğretmen adaylarının Covid-19 pandemi sürecine ilişskin görüşlerini araştırmışlardır. Araştırmaya katılan öğretmen adayları, çocukların sağlıklarının öncelikli olması nedeniyle okulların kapatılmasını olumlu karşıladıklarını söylemişlerdir. Adaylar, bu süreçte uzaktan eğitime geçilmesinden memnun olduklarını dile getirmişlerdir.

Pandemi ile ilgili çalışmaların daha çok sağlık alanında yapıldığg görülmüştür. Buradan hareketle eğitim alanında yapılan çalışmaların az sayıda olduğu söylenebilir. Özellikle alanyazında pandemi döneminde Fen Bilgisi öğretmenlerine yönelik araştırmaların sınırlı sayıda olduğu görülmüştür. Covid-19 pandemi sürecinde en çok etkilenen eğitim paydaşlarından birisi de öğretmenlerdir. Özellikle Fen Bilgisi öğretmenlerinin bu süreçten olumsuz etkilendiğini ifade etmek mümkündür. Çünkü Fen Bilimleri derslerinde birçok konunun öğretilmesinde deneyler önemli yer tutmaktadır ve deneylerin yapılmasında laboratuvara ihtiyaç duyulmaktadır. Dolayısıyla uzaktan eğitim yaklaşımı ile deneylerin yapılmasının zor olması Fen Bilgisi öğretmenlerinin dersleri daha aktif işlemelerini zorlaştırmaktadır. Diğer taraftan Fen Bilgisi öğretmenlerinin pandemi sürecinde karşılaşılaştıkları sorunların belirlenmesinin diğer branş öğretmenlerine yol göstereceği ve bundan sonraki yapılacak çalışmalara da 1şık tutacağı düşünüldügünde bu çalışma önem arz etmektedir. Dolayısıyla bu çalışmanın amacı, Covid-19 pandemi dönemi uzaktan eğitim sürecinde Fen Bilgisi öğretmenlerinin mesleki kazanımlarını ve sorunlarını belirlemektedir. Bu amaç doğrultusunda araştırmanın temel sorusu "Covid-19 pandemi döneminde uzaktan eğitim sürecinde Fen Bilgisi öğretmenlerinin mesleki kazanımları ve sorunları nelerdir?" olarak ifade edilmiştir. Bu temel soruya dayalı olarak araştırmanın alt soruları aşağıdaki gibidir:

- Covid-19 pandemi döneminde uzaktan eğitim sürecinde Fen Bilgisi öğretmenlerinin karşılaştığ temel sorunları nelerdir?

- Covid-19 pandemi döneminde uzaktan eğitim sürecinde Fen Bilgisi öğretmenlerinin mesleki yeterliliği açısından herhangi bir kazanımları var mıdır?

\section{Yöntem}

Bu bölümde araştırmanın desenine, çalışma grubuna, veri toplama aracına, verilerin analizine ve araştırma etiğine dair bilgilere yer verilmiştir. Araştırmada, olgubilim yöntemi kullanılmıştır. Bu yöntem kapsamında Fen Bilgisi öğretmenlerinin uzaktan eğitime ilişkin görüşleri alınmıştır. Öğretmen görüşleri, yarı yapılandırılmış mülakat tekniği aracılığıyla toplanmıştır. Elde edilen verilerin okuyuculara sunulmasından içerik ve betimsel analizden yararlanılmıştır.

\section{Araştırma Deseni}

Araştırma, nitel araştırma yöntemlerinden olgubilim (fenomenoloji) deseni ile yürütülmüştür. Olgubilim, yaşanmış deneyimleri değerlendirme üzerine yoğunlaşan bir yöntemdir (Baltacı, 2019; Jasper, 1994). Bu desenin amacı çalışma grubunun bir durumla ilgili kişisel deneyimlerini inceleyerek olgu ya da olay hakkındaki genel bir anlayışı saptamaktır (Yıldırım ve Şimşek, 2013). Olgubilim deseni farkında olduğumuz fakat ayrıntılı ve derinlemesine bir anlayışa sahip olmadığımız olaylara yoğunlaşmaktadır. Olgular var olduğumuz dünyada deneyimler, algılar, yönelimler, kavramlar, durumlar ve olaylar gibi farklı durumlarda karşımıza çıkabilmektedir. Olgubilim, bireyler tarafından yaşanmış deneyimlerin özünü açıklamaya ve deneyimlenmiş dünyayı tanımlamaya çabalayarak öncelikli olarak olgunun altında yatan ortak anlamları keşfetmeye çalışmaktadır (Baker, Wuest ve Stern, 1992). Bu araştırmada olgubilim deseninin tercih edilmesinde, Fen Bilgisi öğretmenlerinin deneyimleri doğrultusunda, uzaktan eğitim konusunda öğretmenlerin görüşlerinin ele alınmasının etkili olduğu söylenebilir. 


\section{Çalışma Grubu}

Araştırmanın katılımcılarını, 2020-2021 eğitim-öğretimi yılında Doğu Anadolu Bölgesinde yer alan bir ilde görevli 10 Fen Bilgisi öğretmeni oluşturmaktadır. Katılımcıların tamamı devlet okullarında görev yapmaktadır. Katılımcılar, amaçlı örneklem yöntemlerinden kolay ulaşılabilir örneklemeye göre belirlenmiştir. Bu örnekleme türü araştırmaya hız ve pratiklik kazandırdığ 1 için bu çalışmada tercih edilmiştir. Nitel yaklaşımlı araştırmalarda, katılımcıların bir evreni temsil etmesi yerine araştırma konusuyla doğrudan ilişkili olmaları önemlidir (Yıldırım ve Şimşek, 2013). Katılımcıların isimleri kullanılmayarak araştırmanın etik ve gizliliği sağlanmıştır. Katılımcı öğretmenler; Ö1, Ö2, Ö3............̈Ö9, Ö10 kodları ile isimlendirilmiştir. Araştırmaya katılan öğretmenlerin tanımlayıcı demografik özellikleri Tablo 1'de verilmiştir.

Tablo 1

Çalışmaya Katılan Fen Bilgisi Öğretmenlerinin Demografik Özellikleri

\begin{tabular}{llc}
\multicolumn{1}{c}{ Özellik } & Kategori & Sayı \\
\hline Cinsiyet & Kadın & 8 \\
& Erkek & 2 \\
& Toplam & 10 \\
Yaş/ Yıl & $25<\mathrm{x}<30$ & 8 \\
& $30<\mathrm{x}<35$ & 2 \\
Mesleki Tecrübe (yıl) & $0<\mathrm{x}<3$ & 2 \\
Eğitim Seviyesi & $3<\mathrm{x}<6$ & 8 \\
& Lisans & 7 \\
Görev Yaptığı Okulun Yerleşim & Yüksek Lisans & 3 \\
Yeri & İl merkezi & 2 \\
& İlçe merkezi & 3 \\
\hline
\end{tabular}

Tablo 1'de görüldüğg̈ üzere, mülakat yapılan öğretmenlerin 2'si erkek, 8'i kadındır. Katılımcılardan 8 kişi 25 ile 30 yaş aralığında, 2 kişi de 30 ile 35 yaş aralığında bulunmaktadır. Mülakat yapılan öğretmenlerin mesleki tecrübe yılı 1 yıl ve 5 yıl arasında değişmektedir. Araştırmaya katılan öğretmenlerin 3'ü yüksek lisans mezunudur.

\section{Veri Toplama Araçları}

Veriler, yarı yapılandırılmış mülakat formu aracılığıyla toplanmıştır. Covıd-19 pandemi sürecinde Fen Bilgisi öğretmenlerinin öğrenme ortamında karşılaştıkları sorunları belirlemek amacıyla araştırmacılar tarafindan yarı yapılandırılmış mülakat formu oluşturulmuştur. Literatür taraması yapılarak mülakatta yer alacak sorular hakkında fikir sahibi olunmuştur. Bu tarama sonucunda, 12 sorudan oluşan bir soru havuzu oluşturulmuştur. Fen eğitiminde doktora yapmış ve nitel araştırma alanında makalelerinin olduğu tespit edilen iki öğretim üyesinin görüşüne başvurulmuştur. Bunun yanı sıra nitel veri analizi dersini almış üç yüksek lisans öğrencisinin görüşü alınmıştır. Bu uzman görüşleri doğrultusunda yarı yapılandırılmış mülakat formunda yer alan sorular yeniden düzenlenmiştir. Örneğin önceden hazırlanan "Uzaktan eğitim sürecinde kullandığınız ögretim materyalleri nelerdir?" sorusu yapılan düzenlemeler ile "Uzaktan eğitim sürecinde kullandığınız teknolojik ürünler nelerdir?" şeklinde düzeltilmiştir. Ayrıca soru havuzundan bazı sorular çıkarılmıştır. Bu sorulara "Pandemi sürecinde uzaktan eğitim yapabildiniz mi?", "Pandemi öncesinde pandemi ile ilgili ön bilgiye sahipmiydiniz?”, "Laboratuar çalı̧̧ması gerektiren kazanımları uzaktan eğitim ile ögrencilerinize ne tür etkinlikler yaparak vermeye çalıştınız?", "Uzaktan ĕgitim öğrencileriniz ile iletişiminizde bir zaylflığa sebep oldu mu?", "Uzaktan eğitim sürecinde hangi yöntem ve tekniklere yer verdiniz?" örnek verilebilir. Yarı yapılandırılmış mülakat formunun ilk halinde yer alan beş soru araştırma problemi ile ilgili olmaması ve kapsam olarak birbirine benzer olması sebebi ile çıkarılmıştır. Yapılan düzenleme ve değişiklikler ile son hâli verilen yarı yapılandırılmış mülakat formunda yedi soruya yer verilmiştir. Bu bağlamda araştırmada aşağıdaki sorulara cevaplar aranmıştır. 
- Pandemi sürecinde öğrencilerinizin uzaktan eğitime katılma oranları hakkındaki düşünceleriniz nelerdir?

- Uzaktan eğitim sürecinde kullandığınız teknolojik ürünler nelerdir?

- Pandemi sürecinde uzaktan eğitim ile ilgili karşılaştı̆̆ınız problemler nelerdir?

- Pandemi sürecinde öğretim programındaki kazanımları etkili bir şekilde gerçekleştirme konusundaki düşünceleriniz nelerdir?

- Uzaktan eğitimle işlenen derslerde öğrencilerin motivasyon düşüklüğ̈̈ hakkındaki düşünceleriniz nelerdir?

- Uzaktan eğitim sürecinde ögrrenciler ile iletişim kurma konusundaki düşünceleriniz nelerdir?

- Pandeminin mesleki gelişiminizi hangi yönlerde nasıl etkilediğini düşünüyorsunuz?

\section{Verilerin Analizi}

Veriler, betimsel ve içerik analiz yöntemi ile çözümlenmiştir. Katılımcılar ile yapılan mülakatlar, araştırmacılar tarafında düz yazıya çevrilmiştir. Düz yazıya aktarılan ham veriler üzerinde veri indirgemesi yapılmıştır. İlk olarak araştırmacıların dâhil olduğu üç farklı araştırmacı tarafından verilerden; kod, tema ve kategoriler ortaya çıkarılmıştır. Daha sonra üç araştırmacı bir araya gelerek oluşturulan kod ve tema üzerinde uyum oranını belirlemişlerdir. Bu uyum oranın hesaplanmasında, Miles ve Huberman (1994) tarafından önerilen güvenirlik formülü kullanılmıștır. Bu förmül, Güvenirlik=Görüş Birliği/(Görüş Birliği+Görüş Ayrılığı)x100 şeklindedir. Araştırmada kodlayıcılar arasındaki uyum güvenirliği katsayısı \%84 olarak tespit edilmiştir. Elde edilen değer, nitel çalışmalar için yapılan kodlama için güvenilir olduğunu göstermektedir (Miles ve Huberman, 1994). Bu analiz sonucunda ortaya çıkan kategoriler, tema ve kodlar tablo halinde verilmiştir.

\section{Araștırmanın Geçerliliğ̣i ve Güvenirliği}

Nitel araştırmaların geçerliliği ve güvenirliği; inanırlık, tutarlık, genellenebilirlik ve doğrulanabilirlik kavramları ile sağlanmaktadır (Miles ve Huberman, 1994). Çalışmanın inanırlığı için ham veriler ve analizler katılımcıların görüşüne sunulmuştur. Daha sonra verilerin farklı araştırmacılar tarafından kodlanması sağlanıp veri indirgemesi yapılmıştır. Güvenirliği arttırmak için katılımcıların gönüllü öğretmenlerden seçilmesine dikkat edilmiştir. Araştırma soruları açık, net ve süreçle uyumlu olacak şekilde seçilmiştir. Araştırmanın doğrulanabilirliği için ham verilerin/işlenmiş verilerin alındığı doküman eklenmiştir. Araştırmanın geçerliliği için katılımcıların onayı, katılımcıların ayrıntılı tanıtımı ve araştırmacılardan ön yargılardan uzak durması gibi tekniklere başvurulmuştur (Arastaman, Öztürk Fidan ve Fidan, 2018). Üç Fen Bilgisi öğretmeni ve fen eğitimi alanda doktorasını yapmış iki öğretim üyesi mülakat formunda yer alan soruları incelemişlerdir. Böylelikle mülakat formunun geçerliliği sağlanmıștır. Verilerin analiz biçimi başka alan araștırmacıların görüşlerine sunulmuştur. Burada amaç, daha önce oluşturulan kavramsal kategorilerin, temaların ve kodların incelenmesidir. Alan uzmanlarının yapmış olduğu karşılaştırmalar ile araştırmacıların yapmış olduğu karşılaştırmalar arasındaki tutarlılık gözden geçirilmiştir.

\section{Araştırmanın Etiği}

Etik onay ve yazılı izin Van Yüzüncü Yı1 Üniversitesi Sosyal ve Beşeri Bilimleri Yayın Etik Kurulu'ndan (25.03.2021 tarih ve 2021/05-11 sayılı kararı gereği) alınmıştır. Araştırmanın tüm aşamalarında etik ilkelere öncelikle uyulmuştur. Araştırmaya katılan Fen Bilgisi öğretmenleri çalışmaya gönüllülük esasıyla katılmışlardır. Bu kapsamda öğretmenlere araştırmanın amacı ve yöntemi tanıtılmış ve araştırmanın gerekli izinleri de alınmıştır. 


\section{Bulgular}

Fen Bilgisi öğretmenlerinin mülakat formunun "Pandemi Sürecinde Öğrencilerinizin Uzaktan Eğitime Katılma Oranları Hakkındaki Düşünceleriniz Nelerdir?” şeklindeki ilk sorusuna verdikleri cevaplardan elde edilen tema ve kodlar Tablo 2'de verilmiştir.

Tablo 2

Fen Bilgisi Öğretmenlerinin Pandemi Sürecinde Öğrencilerin Uzaktan Eğitime Katılma Oranları Hakkındaki Düşüncelerine İlişkin Kod ve Temalar

\begin{tabular}{llclc}
\hline Ana Tema & Alt Tema & Kodlar & Öğretmenler & f \\
\hline Öğrencilerin Uzaktan & Düşük (10) & 1-2 kişi & Ö1, Ö4, Ö8 & 3 \\
Eğitime Katıllma & & $2-3$ kişi & Ö2, Ö3 & 2 \\
Oranları & & 3-4 kişi & Ö5, Ö6, Ö10 & 3 \\
& & $4-5$ kişi & Ö7 & 1 \\
& & 5-6 kişi & Ö9 & 1 \\
\hline
\end{tabular}

Tablo 2 incelendiğinde katılımcılar Covid-19 salgını döneminde öğrencilerin uzaktan eğitime katılma oranlarının düşük olduğunu ifade etmişlerdir. Derse katılan öğrencilerin $f=1$ ile $f=6$ kişi arasında değiştiği görülmektedir. Örnek öğretmen görüşleri şu şekildedir.

Girdiğim sinıflarda katılım oranı çok düşüktü. Sinıf mevcudu 40 ile 60 kişi arasında değişen sınıflarda katılım iki ile üç kişi arasında değişmektedir (Ö3).

Bir köy okulunda görev yapmaktayım. Bu nedenle okul ve ögrenci imkânları göz önünde bulundurulduğu takdirde uzaktan eğitime katılım oranları süreç boyunca düşük düzeyde seyretti. Birçok ögrencimize hastalık süreci ve klsıtlı imkânlar nedeni ile ulaşamadım (Ö5).

Mülakat formundaki "Uzaktan Ĕ̆itim Sürecinde Kullandığınız Teknolojik Ürünler Nelerdir?” şeklindeki ikinci sorusuna Fen Bilgisi öğretmenlerinin verdikleri cevaplardan elde edilen tema ve kodlar Tablo 3'te verilmiştir.

Tablo 3

Fen Bilgisi Öğretmenlerinin Uzaktan Eğitim Sürecinde Kullandıkları Teknolojik Ürünlere Vermiş Olduğu Cevaplarda Elde Edilen Kod ve Temalar

\begin{tabular}{lllr}
\hline Ana Tema & Alt Tema & Kodlar & f \\
\hline & Bilgisayar & Eba ders içeriği & 10 \\
Uzaktan Eğitim & Tablet & Whatsap & 10 \\
Sürecinde Kullanılan & Telefon & Video & 6 \\
Teknolojik Ürünler & Televizyon & Diğer & 3 \\
& & Web Uygulamaları (z kitap vs.) & 1
\end{tabular}

Tablo 3 incelendiğinde Fen Bilgisi öğretmenleri uzaktan eğitim sürecinde kullandıkları teknolojik ürünlerin bilgisayar, tablet, telefon ve televizyon olduğunu ifade etmişlerdir. Yine aynı tablo incelendiğinde, öğretmenlerin uzaktan eğitim sürecinde öğretim materyali olarak EBA ders içeriğini ( $\mathrm{f}=10)$, Whatsapp'1 ( $\mathrm{f}=10)$, videoları $(\mathrm{f}=6)$, diğer $(\mathrm{f}=3)$, Web uygulamalarını $(\mathrm{f}=1)$ kullandıkları görülmektedir. Örnek öğretmen görüşlerinden bazıları aşağıda verilmiştir.

Kullandiğım teknolojik ürünler, telefon, tablet ve bilgisayar (Ö2).

Bilgisayar ve telefon. Aynı zamanda televizyonumu da akıllı tahta işlevinde kullanıyorum bazı zamanlar. Ögrencilere etkinlikli ya da etkileşimli akallı tahta uygulamaları açmaya çalışıyorum (Ö6).

Fen Bilgisi öğretmenlerinin "Pandemi Sürecinde Uzaktan Eğitim İle İlgili Karşılaştı̆̆ııız Sorunlar Nelerdir?" sorusuna verdikleri cevaplardan elde edilen tema ve kodlar Tablo 4'te verilmiştir. 
Tablo 4

Fen Bilgisi Öğretmenlerinin Pandemi Sürecinde Uzaktan Ĕ̆itim İle İlgili Karşılaştıkları Sorunlara İlişkin Kod ve Temalar

\begin{tabular}{|c|c|c|}
\hline Ana Tema & Alt Tema & Kodlar \\
\hline \multirow[t]{4}{*}{ Bilgisayar kaynaklı sorunlar } & Problem yaşamadım $(\mathrm{f}=4)$ & Bilmeme $(\mathrm{f}=2)$ \\
\hline & Problem yaşadım $(f=6)$ & Bilgisayar aksamları $(\mathrm{f}=3)$ \\
\hline & & Bilgisayar programı $(\mathrm{f}=3)$ \\
\hline & & İnternet bağlantısı $(\mathrm{f}=6)$ \\
\hline \multirow{3}{*}{$\begin{array}{l}\text { İnternet bağlantısı ile yaşanan } \\
\text { problemler }\end{array}$} & Problem yaşamadım $(\mathrm{f}=4)$ & Bağlantı kopması $(\mathrm{f}=6)$ \\
\hline & Problem yaşadım $(\mathrm{f}=6)$ & Bağlantı yavaşlığ $1(f=6)$ \\
\hline & & Aşırı yoğunluk $(\mathrm{f}=6)$ \\
\hline \multirow[t]{6}{*}{ Öğrenciler ile yaşanan problemler } & Problem yaşamadım $(\mathrm{f}=2)$ & Dersi sabote etme $(\mathrm{f}=2)$ \\
\hline & Problem yaşadım $(\mathrm{f}=8)$ & Öğretmen-öğrenci iletişim güçsüzlüğü (f=4) \\
\hline & & $\begin{array}{l}\text { Öğrencilerde isteksizlik / motivasyon } \\
\text { düsüklüğü }(f=7)\end{array}$ \\
\hline & & $\begin{array}{l}\text { Öğrencinin bilgisayara/internete erişememesi } \\
(\mathrm{f}=8)\end{array}$ \\
\hline & & Öğrencilerin programları bilmemesi $(\mathrm{f}=8)$ \\
\hline & & Derslere katılım düşüklüğü (f=10) \\
\hline \multirow[t]{3}{*}{ Zümre ile yaşanan problemler } & Problem yaşamadım $(\mathrm{f}=5)$ & İletişim kopukluğu (f=2) \\
\hline & Problem yaşadım $(\mathrm{f}=2)$ & Bilgiyi paylaşmama $(\mathrm{f}=1)$ \\
\hline & Zümrem yok $(\mathrm{f}=3)$ & \\
\hline \multirow{5}{*}{$\begin{array}{l}\text { Okul yönetimi ile yaşanan } \\
\text { problemler }\end{array}$} & Problem yaşamadım $(f=6)$ & Öğretmene danışmama (f=1) \\
\hline & Problem yaşadım $(\mathrm{f}=2)$ & Beklenti yüksekliği $(\mathrm{f}=1)$ \\
\hline & Yanit yok $(\mathrm{f}=2)$ & Süreci bilmeme $(\mathrm{f}=2)$ \\
\hline & & Bitmeyen talepler $(\mathrm{f}=2)$ \\
\hline & & Bask1 $(\mathrm{f}=2)$ \\
\hline
\end{tabular}

Tablo 4 incelendiğinde öğretmenler, bilgisayar kaynaklı sorunlar başlıklı ana temaya ait; internet bağlantısı $(\mathrm{f}=6)$, bilgisayar programı $(\mathrm{f}=3)$, bilgisayar aksamları $(\mathrm{f}=3)$ ve bilgisayar kullanımını bilmeme $(\mathrm{f}=2)$ konularında sıkıntı yaşadıkları görülmektedir. Katılımcıların internet bağlantısı ile yaşadıkları problemleri ise; aşırı yoğunluk ( $f=6)$, bağlantı yavaşlı̆̆ $(f=6)$ ve bağlantı kopması (f=6) kodları ile açıklamışlardır. Örnek öğretmen görüşlerinden bazıları aşağıda verilmiştir.

Evlerinde bilgisayar ve internet olmayan ögrrenciler çok fazla. Derse bağlansalar bile bu sefer alt yap yetersizliğinden dolayı siklıkla dersten düşmeler, ses gitmesi, derse katılmada isteksizlik gibi problemlerle karşılaştım (Ö9).

Bazılarında ses sıkıntısı yaşanmaktadır. Sesimin onlara gitmemesi ve onlardan ses alamamak gibi bu da eğitimde dönüt durumunu ve iletişimi zorlaştırmaktadır (Ö7).

Fen Bilgisi öğretmenleri çevrimiçi eğitim sürecinde öğrencileri ile yaşanan sıkıntıları; öğrencilerin derslere katılım düşüklüğü $(\mathrm{f}=10)$, öğrencinin internete/bilgisayara erişememesi $(\mathrm{f}=8)$, öğrencilerin programları bilmemesi $(\mathrm{f}=8)$, öğrencilerde isteksizlik/motivasyon düşüklüğü $(\mathrm{f}=7)$, öğretmen-öğrenci iletişim güçsüzlüğü $(\mathrm{f}=4)$ ve canlı dersleri sabote etmeleri $(\mathrm{f}=2)$ olarak ifade etmişlerdir. Örnek öğretmen görüşleri şu şekildedir.

Kısıtlı imkânlar uzaktan eğitime erişimi de kısıtladı. Çoğu ögrencimin evinde internet yok. Evinde internet olaninda tek bir teknolojik aleti olmast ve uzaktan eğitime katılan kardeş saylsinin fazla olması gibi sıkıntılardan dolayı bazı öğrencilerim her dersime katılamıyor. Derslerde ögrenci ile ögretmen arası etkileşim azaldı (Ö2).

En büyük problem kısıtlı imkânlar ve derslere katılamamak. Bunun yanında büyük bir sorun ise internete erişiminin olmaması. Çoğunlukla bilgisayar, tablet veya akıllı bir cihazın evde bulunmaması veya kalabalık bir ailede yetişen çocuğun derslere katılım sağlayacağ kişisel bir cihazının olmaması uzaktan eğitim sürecinde karşılaşı̆ğımız en büyük problemlerden olmuştur (Ö5). 
Uzaktan eğitim henüz yapım aşamasında bana göre ama ilgilenen ve uğraş veren çocuk problemleri çözebiliyor. EBA'ya girmek bir sorundu önce sonra Zoom odaklı dersler olmaya başladl. Öğrenciler zamanla bu problemleri de çözdü diye düşünüyorum. Ancak tabi ki yüz yüze eğitimle klyaslamıyorum uzakan eğitimi bence en büyük problem ülkemizin henüz uzaktan eğitime hazır olmamamsı. Çocuklarımızın hatta birçok yetişkinimizin bile oto kontrolü olmadığını düşünüyorum. Ögrencilerimizin en büyük problemi oto kontrolü sağlamaktır (Ö6).

Öğretmenlerin büyük bir kısmı (f=6) çevrimiçi eğitim sürecinde zümreleri ile sıkıntı yaşamadıkları Tablo 4'de görülmektedir. Sıkıntı yaşayan iki öğretmen; bilgiyi paylaşmama ( $\mathrm{f}=1)$ ve iletişim kopukluğu $(\mathrm{f}=2)$ konusunda problemler yaşadıklarını ifade etmişlerdir.

Tablo 4'e göre öğretmenlerin çoğu ( $\mathrm{f}=6)$ okul yönetimi ile çevrimiçi eğitim sürecinde sıkıntı yaşamadıklarını belirtmişlerdir. Sıkıntı yaşayan iki öğretmen, kendilerine baskı yapılmasından ( $\mathrm{f}=2)$, süreci bilmemelerinden dolayı oluşan belirsizlikten $(\mathrm{f}=2)$, okul yönetiminin bitmeyen taleplerinden $(\mathrm{f}=2)$, ders saatleri konusunda öğretmene danışılmamasından $(\mathrm{f}=1)$ ve normal bir süreçteki gibi başarı beklentilerinin yüksek olmasından ( $\mathrm{f}=1$ ) doğan sıkıntıların olduğunu ifade etmişlerdir. Bu konuda Ö4 öğretmenine ait görüş aşağıda verilmiştir.

İdarenin gün içerisinde daima talepte bulunması, sabah akşam ögretmenlik sürecini çok can sıkıcı bir durum haline getirdi (Ö4).

Fen Bilgisi öğretmenlerinin mülakat formunun "Pandemi Sürecinde Öğretim Programındaki Kazanımları Etkili Bir Şekilde Gerçekleştirme Konusundaki Düşünceleriniz Nelerdir?” şeklindeki dördüncü sorusuna verdikleri cevaplardan elde edilen tema ve kodlar Tablo 5'de verilmiştir.

Tablo 5

Fen Bilgisi Öğretmenlerinin Pandemi Sürecinde Öğretim Programındaki Kazanımları Gerçekleştirebilme Konusundaki Düşüncelerine İliş̧in Kod ve Temalar

\begin{tabular}{lll}
\hline Ana Tema & Alt Tema & Kodlar \\
\hline $\begin{array}{l}\text { Pandemi sürecinde öğretim } \\
\text { programındaki kazanımları } \\
\text { etkili bir şekilde gerçekleştirebilme }\end{array}$ & Gerçekleştirilemedi (f=10) & $\begin{array}{l}\text { Ortamı̆rencilere ulaşılamaması }(\mathrm{f}=10) \\
\text { Öğrencilerin pasif olmasi }(\mathrm{f}=4)\end{array}$ \\
$\begin{array}{l}\text { Ders süresinin yetersiz olması } \\
(\mathrm{f}=4)\end{array}$
\end{tabular}

Tablo 5 incelendiğinde Fen Bilgisi öğretmenlerinin pandemi sürecinde kazanımları etkili bir şekilde gerçekleştiremedikleri görülmektedir. Fen Bilgisi öğretmenleri kazanımları etkili bir şekilde gerçekleştirememe sebeplerini; tüm öğrencilere ulaşılamaması $(\mathrm{f}=10)$, öğrencilerin ders ortamlarının uygun olmaması $(f=4)$, öğrencilerin pasif olması $(f=4)$ ve ders süresinin yetersiz olması $(f=6)$ şeklinde ifade etmişlerdir. Örnek öğretmen görüşlerinden birkaçı şu şekildedir.

Çok az öğrenci olduğu için kazanımları her öğrenciye kazandıramadım. Somut öğrenmeye ve deneye dayalı bir ders olduğu için çok verimli olmuyor. Soru çözümleri (özellikle çarprazlama vs.) verimli yapılamıyor. Bu şekilde ögretim programın tamamlayabileceğimi düşünmüyorum (Ö4).

Derslere katılım oranın yeterli düzeyde olmaması ve ögrencilerin bu süreçte dersleri düzenli takip edememe problemi üzerine kazanımlar etkili bir şekilde ögrencilere verilememiştir (Ö5).

Öğrenciler tek sobalı bir odada tüm aile fertleri ile birlikte oldukları için derse aktif bir şekilde katılamıyorlar. Sinı ortamı gibi bir ortamın olmaması kazanımları etkili bir şekilde gerçekleştirebilmenin en büyük engeli oluşturuyor (Ö2).

Öğretmenlerin mülakat formunun "Uzaktan Ĕ̈itimle İslenen Derslerde Öğrencilerin Motivasyon Düşüklüğü Hakkındaki Düşünceleriniz Nelerdir?'” şeklindeki beşinci sorusuna verdikleri cevaplardan elde edilen tema ve kodlar Tablo 6'da verilmiştir. 
Tablo 6

Fen Bilgisi Öğretmenlerinin Uzaktan Ĕ̆itim Sürecinde Ö̆̆rencilerin Motivasyon Düşüklüğ̈̈ Hakkındaki Görüşlerine Ilişkin Kod ve Temalar

\begin{tabular}{lll}
\hline Ana Tema & Alt Tema & Öğretmenler/Frekans \\
\hline \multirow{3}{*}{ Uzzaktan Eğitim Sürecinde } & Aşırı kaygının olmas1 & Ö2, Ö5, Ö8 (f=3) \\
Öğrencide Motivasyon & Uygun öğrenme ortamının olmamas1 & Ö2, Ö4, Ö8 (f=3) \\
Düşüklüğü & Yüz yüze etkileşimin olmaması & Ö1, Ö3 (f=2) \\
& Sosyallaşmenin olmaması & Ö9, Ö10 (f=2) \\
& Oto kontrol & Ö6 (f=1) \\
& Dikkat dağınıklı̆̆ın olmas1 & Ö7 (f=1) \\
& Sinav modu & Ö4 (f=1) \\
& İsteksizlik & Ö6 (f=1) \\
\hline
\end{tabular}

Fen Bilgisi öğretmeni uzaktan eğitim sürecinde öğrencilerde meydana gelen motivasyon düşüklüğünü, aşırı kaygı düşüklüğü $(\mathrm{f}=3)$, uygun öğrenme ortamının olmaması $(\mathrm{f}=3)$, yüz yüze etkileşimin olmaması $(\mathrm{f}=2)$ ve sosyalleşmenin olmaması $(\mathrm{f}=2)$ kodları ile açıklamışlardır. Ayrıca öğretmenler öğrencilerdeki motivasyon düşüklüğünü; oto kontrol $(f=1)$, dikkat dağınıklığın olması $(\mathrm{f}=1)$, sınav modunun olması $(\mathrm{f}=1)$ ve isteksizlik $(\mathrm{f}=1)$ kavramları ile ifade etmişlerdir. $\mathrm{Bu}$ konuda örnek öğretmen görüşleri aşağıda verilmiştir.

Motive olamadıklar bir gerçektir. Dediğim gibi oto kontrol sağlayamadıkları için kendi kendilerine nasıl çalışacaklarını bilmiyorlar. Okulların durumu da belli olmadiğı için büyük bir isteksizlik var (Ö6).

Ögrrenci ders ve sınav moduna giremiyor. Öğrenci uygun bir öğrenme ortamina sahip olamadığı için odaklanamıyor. Motivasyon için çeşitli duyguları ögrenciye geçiremiyoruz (Ö4).

Öğretmenlerinin mülakat formunun "Uzaktan Eğitim Sürecinde Öğrenciler İle İletişsim Kurma Konusundaki Düşünceleriniz Nelerdir?" şeklindeki altıncı sorusuna verdikleri cevaplardan elde edilen tema ve kodlar Tablo 7'de verilmiştir.

Tablo 7

Fen Bilgisi Öğretmenlerinin Uzaktan Ĕgitim Sürecinde Öğrenciler İle İletişsim Kurma Konusundaki Düsüncelerine Illişkin Kod ve Temalar

\begin{tabular}{llll}
\hline Ana Tema & Alt Tema & Kodlar & Öğretmenler/Frekans \\
\hline & Whatsapp & Maddi imkânların yetersizliği & Ö3, Ö4, Ö7, Ö8, Ö10 (f=5) \\
$\begin{array}{l}\text { Uzaktan Eğitim } \\
\begin{array}{l}\text { Sürecinde Öğrenciler İle } \\
\text { Iletişimi Sağlama }\end{array}\end{array}$ & ZBA Canlı Ders & Öğretmen-veli arasındaki & Ö1, Ö2, Ö6, Ö9 (f=4) \\
& & iletişim zayıflığ1 & \\
& & Velinin ilgisizliği & Ö5, Ö8, Ö9 (f=3) \\
\hline
\end{tabular}

Tablo 7 incelediğinde Fen Bilgisi öğretmenlerinin uzaktan eğitim sürecinde öğrenciler ile Whatsapp, EBA ve Zoom programları aracılığıyla iletişim sağladıklarını ifade ettikleri görülmektedir. Öğretmenler, maddi imkânların yetersizliği (f=5), öğretmen-veli arasındaki iletişim zayıflığ $1(\mathrm{f}=4)$ ve velinin ilgisizliği $(\mathrm{f}=3)$ gibi unsurlardan dolayı iletişim sağlama konusunda zorlandıklarını belirtmişlerdir. Bu konudaki örnek öğretmen görüşleri aşağıda verilmiştir.

Öğrencilerim kendi telefonları olmadı̆̆ için iletişim zor oluyor. Ailelerini arayınca veya ödev atınca evde olmayabiliyorlar. İternet sorunu da yine burada karşımıza çıkıyor (Ö4).

Genellikle ögrencilerde bu süreçte whatsapp üzerinden konuşuyoruz anlamadıkları ya da yapamadıkları soruları buradan bana fotoğrafinı atarak cevaplandırmaya çalışıyorum. Ancak her ögrencinin evinde ya da telefonunda internet olmadı̆̆ için ulaşamadı̆̆ım veli ve öğrenciler de var (Ö7). 
Çevrimiçi mesajlaşma programları ile iletişime geçmeye çalışsam da bazı sınıflarda neredeyse hiç iletiş̧im kuramadı̆̆ım ögrenci ve veliler oldu. Aradığım zaman telefonu açmayan velilerle karşılaş̧ım. Ya da mesajımı okumayan iki gün sonra dönüş yapan ögrenciler oldu. Bu iletişimsizlik onlarda da bende de derse katılımlarda isteksizliğe sebep oldu. Derse katılan ögrrenciler sık sık bağlantı problemi yaşadiğı için dersle alakalı sorularımda cevap alamadiğım zamanlar oldu. Sorucevap yöntemi düz anlatım yöntemine döndü çoğu zaman (Ö9).

Fen Bilgisi öğretmenlerinin mülakat formunun "Pandeminin Mesleki Gelişiminizi Hangi Yönde Nasıl Etkilediğini Düşünüyorsunuz?" şeklindeki son sorusuna verdikleri cevaplardan elde edilen tema ve kodlar Tablo 8'de verilmiştir.

Tablo 8

Fen Bilgisi Öğretmenlerinin Pandeminin Mesleki Gelişimlerini Hangi Yönde Nasıl Etkilediklerine İlişkin Düşüncelerine Yönelik Kod ve Temalar

\begin{tabular}{|c|c|c|}
\hline Ana Tema & Alt Tema & Kodlar \\
\hline \multirow[t]{3}{*}{ Teknolojileri kullanımı } & Etkiledi $(\mathrm{f}=8)$ & Farklı programları keşfetme $(\mathrm{f}=8)$ \\
\hline & Etkilemedi $(\mathrm{f}=2)$ & Teknoloji kullanımının artması $(\mathrm{f}=8)$ \\
\hline & & Online platformları kullanmaya başlama $(\mathrm{f}=8$ ) \\
\hline \multirow[t]{6}{*}{ Mesleki doyum } & Etkiledi $(\mathrm{f}=6)$ & Olumsuz Etkiledi $(f=6)$ \\
\hline & Etkilemedi ( $\mathrm{f}=4)$ & Öğrencilerle iletişim kuramama $(\mathrm{f}=6)$ \\
\hline & & Yüz yüze eğitimden yoksunluk (f=6) \\
\hline & & Olumlu Etkiledi $(\mathbf{f}=\mathbf{4})$ \\
\hline & & Daha aktif olma $(\mathrm{f}=2)$ \\
\hline & & Kendini geliştirmeye vakit ayırabilme (4) \\
\hline \multirow[t]{14}{*}{ Mesleki gelişim } & Etkiledi $(\mathrm{f}=4)$ & Olumsuz Etkiledi $(f=4)$ \\
\hline & Etkilemedi $(\mathrm{f}=2)$ & Herkesin farklı uygulamaya başvurması ( $f=2$ ) \\
\hline & Hem olumlu hem olumsuz & Bilgi körelmesi oluşması ( $\mathrm{f}=2$ ) \\
\hline & etkiledi $(\mathrm{f}=2)$ & Okula olan hasretin artması $(\mathrm{f}=2)$ \\
\hline & Yanit yok (f=2) & Öğrenciyle iletişimde güçlük (f=1) \\
\hline & & Boşluk hissi oluşması $(\mathrm{f}=1)$ \\
\hline & & Olumlu Etkiledi $(f=4)$ \\
\hline & & Farklı alanda öğrenci ile iletişim kurma (f=2) \\
\hline & & Daha az yorulma $(\mathrm{f}=2)$ \\
\hline & & Kendine olan güven hissinin gelişmesi $(\mathrm{f}=3$ ) \\
\hline & & Kendini geliştirme firsat $(\mathrm{f}=4)$ \\
\hline & & Hem olumsuz hem olumlu etkiledi $(\mathrm{f}=2)$ \\
\hline & & $\begin{array}{l}\text { Yüz yüze eğitimden yoksunluk, farklı bir } \\
\text { tecrübe yaşama }(\mathrm{f}=1)\end{array}$ \\
\hline & & $\begin{array}{l}\text { Sinıf hâkimiyeti sağlayamama, kendini } \\
\text { gelistirme firsatı }(\mathrm{f}=1)\end{array}$ \\
\hline \multirow{3}{*}{$\begin{array}{l}\text { Öğretmenlik mesleğine/ } \\
\text { branşa yönelik tutum }\end{array}$} & Değişti (f=4) & Mesleğin kutsallığının anlaşılması ( $\mathrm{f}=4$ ) \\
\hline & Değişmedi (f=2) & Bilimin öneminin anlaşılması ( $\mathrm{f}=2$ ) \\
\hline & Yanit Yok (f=4) & Deney yapmanın öneminin anlaşılması $(\mathrm{f}=1)$ \\
\hline
\end{tabular}

Tablo 8 incelendiğinde pandemi sürecinin katılımcıların eğitim alanındaki teknoloji kullanımlarını olumlu yönde etkilediği görülmektedir. Fen Bilgisi öğretmenleri salgın sürecinde; çevrimiçi platformları kullanmaya başlama $(\mathrm{f}=8)$, farklı programları keşfetme $(\mathrm{f}=8)$ ve teknoloji kullanımının artması (f=8) gibi kavramlarının hayatlarında önemli yer aldığını ifade etmişlerdir. $\mathrm{Bu}$ konudaki öğretmen görüşlerinden bazıları aşağıda verilmiştir.

Daha fazla teknolojik aletlerle ve teknolojiyle haşır neşir oluşumuz aslında bilmediğimiz görmediğimiz birçok uygulama ve web sitelerinden haberdar olmamızı sağladı (Ö3).

Teknolojik aletlerin daha çok kullanılmasını sağladı. Derste teknolojik araç gereçlerin kullanılmasını olumlu yönde etkiledi (Ö1). 
Fen Bilgisi öğretmenleri salgın sürecinde mesleki doyumlarının olumlu veya olumsuz olarak etkilendiğini belirtmiş̧lerdir. Öğretmenler, öğrencilerle iletişim kuramama (f=6) ve yüz yüze eğitimden yoksun olma ( $\mathrm{f}=6$ ) gibi değişkenleri gerekçe göstererek mesleki doyumlarının olumsuz etkilendiğini ifade etmişlerdir. Mesleki doyumlarını olumlu etkilediğini ifade eden öğretmenler, öğrencilerle iletişimde daha aktif oldukları $(\mathrm{f}=2)$ ve kendini geliştirmeye vakit ayırabildikleri $(\mathrm{f}=4)$ değişkenleri ile açıklamışlardır. Bu konuda iki öğretmen görüşü örnek olarak aşağıda verilmiştir.

EBA platformunu daha etkili kullandiğımı düşünüyorum. Zoom gibi bir programla tanıştım. Açıç̧ası daha klasik yöntemler kullanıyordum okuldayken. Süreç içinde akıllı tahta uygulamaları dediğimiz z-kitap ve etkileşimli etkinlikleri daha çok kullandım. Ama yine de okuldaki gibi doyum aldığımı düşünmüyorum (Ö9).

Aslına bakllırsa pandemi teknoloji olarak bizi bir tık daha üst seviyeye taşıld. Zamanla bu teknoloji çağına alışıp, oto kontrolümüzü sağlayacă̆ımıza eminim. Zamanla öğrenciler de bunu öğrenecek diye düşünüyorum. Klyaslayacak olursak birçok öğrenci internette ulaşabileceği kaynakların farkında değilken şuan birçoğu Zoom'dan canlı derslere katılp, internetten ders izliyorlar. Bu bile bizim uyum yeteneğimizin ne kadar ilerlediğinin kanttı bence. Kendi adıma da pandemi sürecinde birçok kaynă̆ın farkına varıp on-line eğitimler alabildim, on-line seminerlerle kendimi geliştirme firsatı bulabildim (Ö6).

Fen Bilgisi öğretmenleri, Covid-19 salgınının mesleki alandaki gelişimlerini olumlu yönde katk1 sağladığını belirtmişlerdir. Öğretmenler, zor şartlar altında eğitimi sürdürebildikleri için kendilerine olan güven hislerinin geliştiğini $(\mathrm{f}=3)$, kendilerini geliştirme firsatı bulduklarını $(\mathrm{f}=4)$, farklı alanda öğrenci ile iletişim kurduklarını $(\mathrm{f}=2)$ ve çevrimiçi eğitim sürecinde daha az yorulduklarını ( $\mathrm{f}=2$ ) ifade etmişlerdir. Dört öğretmen ise Covid-19 salgınının mesleki gelişimlerini olumsuz olarak etkilediğini ifade etmiştir. Öğretmenler bu görüşlerini; herkesin farklı uygulama kullanması $(\mathrm{f}=2)$, uzaktan eğitim sürecinde bilgi körelmesinin yaşanması $(\mathrm{f}=2)$, okula özlem hissinin artması ( $\mathrm{f}=2)$, uzaktan eğitim sürecinde öğrenciyle iletişimde zorluk yaşanması $(\mathrm{f}=1)$ ve boşluk hissi $(\mathrm{f}=1)$ kodları ile desteklemişlerdir. Yine iki öğretmen salgın sürecinin mesleki gelişimlerini hem olumlu hem de olumsuz etkilediğini iki öğretmen belirtmiştir. Öğretmenler bu düşüncelerini; sınıf hâkimiyeti sağlayamama, kendini geliştirme firsatı, yüz yüze eğitimden yoksunluk ve farklı bir tecrübe yaşama kavramları ile açıklamışlardır. Mülakatın bu sorusuna verilen cevaplardan bazıları aşağıda sunulmuştur.

Teknoloji hakkında daha kapsamlı bilgi sahibi olup bunları aktif bir şekilde kullanıorum

Yüz yüze eğitimin daha etkili olduğunu düşünüyorum. Konulart yüz yüze anlatamamak pekiştiremememize neden oluyor. Bu da bende bilgi körelmesi oluşturdu (Ö5).

İki yönden de etkiledi uzaktan öğretim sürecinde on-line eğitim konusunda kendimizi geliş̧tirdik fakat evde kaldığımız için eğitim öğretim sürecinde bazı eksiklikler oluşuyor (Ö8).

Fen Bilgisi öğretmenlerinin pandemi sürecinde öğretmenlik mesleğine/branşına yönelik tutumlarının olumlu yönde değiştiğine yönelik bulgular Tablo 8'de verilmiştir. Tutumu olumlu yönde değişenler $(\mathrm{f}=4)$; öğretmenlik mesleğinin kutsal bir meslek olduğunun anlaşılması ( $\mathrm{f}=4)$ ve bilimin öneminin anlaşılması $(\mathrm{f}=2)$ şeklinde düşüncelerini ifade etmiştir. Bazı öğretmen görüşleri aşağıda verilmiştir.

Öğretmenlik mesleğinin kutsal bir meslek olduğunu bu süreçte yaşarak görmüs oldum ve eğitimini yüz yüze yapabilmenin ne kadar önemli olduğunu bu süreçte yaşadıklarım ile daha iyi daha anlamış oldum (Ö4).

Tutumumda bir değişim olmadl. Bu süreçlerin hepsini atlatıp yüz yüze eğitim dönemine geçtiğimizde kaldı̆̆ımız yerden öğrencilerimizle devam edeceğiz (Ö10). 


\section{Sonuç, Tartışma ve Öneriler}

Fen Bilgisi öğretmenleri, Covid-19 pandemi döneminde öğrencilerinin uzaktan eğitime katılma oranlarının düşük olduğunu belirtmişlerdir. Öğretmenler öğrencilerin uzaktan eğitime katılım oranının düşük olmasını; her evde internetin olmaması, bilgisayar ve tablet sayısının sınırlı olması, okula giden kardeş sayısının çok fazla olması nedeniyle yeterli teknolojik araçların olmamasıyla açıklamışlardır. Birçok ailede öğrencilerin derslere, akıllı telefonlar aracılığıyla katıldığı ve bu akıllı telefonların velilere ait olduğu düşünülmektedir. Veliler işte olduğu zaman, öğrenciler uzaktan eğitimdeki derslerine katılmadıkları öğretmenler ile yapılan görüşmelerde ortaya konulmuştur. Uzaktan eğitimin başladığı ilk aylarda internet bağlantısı olan ve yeterli teknolojik araç gereçlerin olduğu evlerde uzaktan eğitime bağlanmada bir takım sıkıntılar olmuştur. İnternet bağlantısını sağlayan şebekelerin yeterli alt yapılarının olmaması ve internet kullanıcı sayısının birden artmasının bu konuda etkili olduğu söylenebilir. Evlerinde internet erişimi bulunan ailelerde, internet erişiminin hanede bulunan ebeveynlerin veya başka bir bireyin cep telefonu üzerinden sağlanıyor olması gibi durumlarda, öğrenci tarafindan internet erişiminin kullanılabilmesi muhtemel olmayabilir (Türk Eğitim Derneği Düşünce Kuruluşu [TEDMEM], 2020). Bayburtlu (2020) da Türkçe öğretmenleri ile yürüttüğü bir çalışmada, öğrencilerin bir kısmında tablet, bilgisayar gibi cihazların olmayışından canlı derslere katılamadıklarını ve velilerin bir kısmının bu süreçte ilgisiz olduğu sonucuna ulaşmıştır. Ayrıca öğrencilerin derslere katılım düzeylerinin istenilen seviyede olmadığını saptanmıştır. Bu çalışmada elde edilen sonuçlar, bu konuda daha önce yapılan çalışmaların sonuçları ile benzerlik göstermiştir. $\mathrm{Bu}$ açıdan bakıldığında yaklaşık bir yıldır devam eden uzaktan eğitime öğrencilerin katılma oranlarının hala düşük olması oldukça manidar bir durumdur.

Araştırmaya katılan öğretmenler uzaktan eğitim sürecinde; bilgisayar, tablet ve telefon gibi teknolojik ürünleri kullandıklarını ifade etmişlerdir. Bu teknolojik araçların tercih edilmesinde, temin edilmelerinin kolay olması, günlük hayat için gerekli olan teknolojik araçlar olması ve temel iletişim araçları olmalarının etkili olduğu düşünülmektedir. Covid-19 pandemi sürecinde yapılan çalışmalar incelendiğinde, uzaktan eğitim yaklaşımında öğretmenler bilgisayar, tablet, cep telefonu ve TRT EBA TV'yi kullanmışlardır (Arslan ve Şumuer, 2020; Karakuş, Ucuzsatar, Karacaoğlu, Esendemir ve Bayraktar, 2020). Öğretmenler uzaktan eğitim sürecinde EBA ders içeriği, whatsap, videolar ve web uygulamalarını (z kitap vs.) öğretim materyali olarak kullandıklarını ifade etmişlerdir. Öğrencileri ile iletişim halinde bulunan öğretmenler verdikleri ödevleri öğrencilerinin ebeveynlerinin de dâhil olduğu sınıf whatsapp grubu üzerinden takip edebilmektedir. Bunun yanı sıra öğrenciler derslerle ilgili anlamadığı bir nokta olduğunda, öğretmenlerine telefon ile ulaşıp anlamadıkları noktaları sorabilmektedirler.

Araştırmaya katılan öğretmenler uzaktan eğitim sürecinde iki temel sorun ile karşılaştıklarını belirtmişlerdir. Bu sorunlardan birincisi öğretmenlerin uzaktan eğitimde kullanılan teknolojik araçları kullanma konusunda yaşadıkları sorunlardır. Bunlar; öğretmenlerin bilgisayarı yeterli düzeyde kullanamamaları, bilgisayar programlarını bilmemeleri, internet bağlantısı ve bilgisayar kaynaklı sorunlar şeklinde ifade edilmiştir. Elde edilen sonuçların, yurt içinde ve yurt dişında yapılan çalışamaların sonuçları ile büyük oranda örtüştüğü görülmektedir. Örneğin Burke ve Dempsey (2020) tarafından İrlanda'da yapılan bir çalışmada, uzaktan eğitimde kullanılan teknolojik araçları kullanma konusunda öğretmenlerin görüşleri araştırılmıştır. $\mathrm{Bu}$ araştırmada öğretmenlerin uzaktan eğitim konusunda yeterli donanıma sahip olmadıkları, yazılım ve teknolojik ürünleri istenilen düzeyde kullanamadıkları tespit edilmiştir. Uzaktan eğitim sürecinde öğretmenlerin yaşadıkları sorunlardan ikinci ise öğrenci kaynaklı sorunlardır. Öğrencilerin uzaktan eğitim sürecine katılma konusunda isteksiz olmaları ve öğrencilerin bilgisayara/internete erişimde sıkıntı yaşamaları olduğu belirlenmiştir. $\mathrm{Bu}$ durum, öğrencilerin derslere katılımlarını zorlaştırdığı için öğrencilerde motivasyon düşüklüğüne neden olmaktadır. Bakioğlu ve Çevik (2020) tarafından Fen Bilgisi öğretmenlerinin uzaktan eğitime ilişkin görüşlerinin araştırıldığı çalışmada, uzaktan eğitimin öğrencilerde motivasyon düşüklüğüne neden olduğunu belirlenmiştir.

Fen Bilgisi öğretmenleri uzaktan eğitim ile öğretim programındaki kazanımları yeterli düzeyde gerçekleştiremediklerini belirtmişlerdir. Bu durumu, öğretmenler uygun öğrenme ortamının 
olmaması ile açıklamışlardır. Çalışmaya katılan öğretmenler; öğrencilerin ailedeki hane halkı sayısının fazla olması, evlerin öğrenme ortamı için uygun ve ailelerin sosyo-ekonomik durumlarının iyi olmaması gibi değişkenlerin kazanımların gerçekleştirilmemesinde etkili olduğunu dile getirmişlerdir. Örneğin, hane halkının tamamının bulunduğu bir odada derse katılmaya çalışmakta olan öğrencilerin derslerden istenilen verimi almakta zorlanacakları düşünülmektedir. Uzaktan eğitimde ders süresinin yetersiz olması ve öğrencinin internet/bilgisayar erişiminde sıkıntı yaşamasından dolayı derse katılım oranlarının az olması gibi sebepler de kazanımların etkili gerçekleştirilmesini olumsuz etkilemektedir. (Arslan ve Şumuer, 2020). Çakın ve Külekçi-Akyavuz (2020) Covid-19 süreci ve eğitime yansımasını ortaya çıkarmak için yaptıkarı çalışmada öğretmenlerin görüşlerini almışlardır. Öğretmenler, uzaktan eğitim sürecinde öğrencilerin ders katılma konusunda isteksiz olduklarını, uygun öğrenme ortamlarının olmadığını ve bazı öğrencilerin aile ortamlarının derse katılma için uygun olmadığını belirtmişlerdir. Öğretmenler bu olumsuzlukları ortadan kaldırmak için, öğrencilere destekleyici etkinlikler yapmışlar ve güzel sözler söylemişlerdir. Covid-19 pandemi sürecinde öğretmenler ile yapılan çalışmalarda benzer sonuçlara ulaşmışlardır.

Araştırmaya katılan öğretmenler, uzaktan eğitim sürecinde motivasyon düşüklüğü olduğunu ifade etmişlerdir. Öğretmenler ayrıca motivasyon düşüklüğünün aynı zamanda öğrencilerde büyük bir kaygı oluşturduğunu da ifade etmişlerdir. Öğrencilerde oluşan bu kaygınının nedenlerini öğretmenler; mutsuzluk, uzaktan eğitimde kendini yetersiz hissetme, öğrencilerdeki bilgi eksikliği ve öğretmenleri ile aktif iletişim kuramama olarak açıklamışlardır. Covid-19 pandemi sürecinde uzaktan eğitim yaklaşımında, öğretmenler ile öğrenciler arasında iletişim kopukluğu olduğuna dair birçok çalışma bulunmaktadır (Arslan ve Şumuer, 2020; Duban ve Şen, 2020). Öğretmen ve öğrenciler gibi çoğu insan, salgın sırasında evde durmak zorunda kalmış bu da bireyleri daha fazla endişelenmeye yöneltmiştir (Bakioğlu ve Çevik, 2020). Öğretmenler öğrencilerdeki motivasyon düşüklüğünün bir diğer nedenini ise uygun bir öğrenme ortamının olmayışı şeklinde ifade etmişlerdir. Kişi sayısının fazla olduğu ailelerde öğrencilerin uygun öğrenme ortamı bulmakta zorlandıkları düşünülmektedir. Dolayısıyla, uzaktan eğitim sürecinde ev ortamının öğrencilerin derse olan motivasyonunu belirlemede önemli bir faktör olduğu düşünülmektedir. Motivasyon düşüklüğüne sebep olan diğer faktörlerden biri de yüz yüze etkileşimin olmamasından kaynaklı öğrencilerin sınav moduna girmelerinde sıkıntı yaşamalarıdır. Öğrencilerin okulda olmamaları ve arkadaşlarından ayrı kalmaları onları sosyallikten uzaklaşmalarını neden olmuştur. Bunun yanı sıra öğrenciler, kendi kendilerine nasıl çalışacaklarını unutmuşlar. Bütün bunlar öğrencilerde oto kontrol sorununu meydana getirmiştir (Çakın ve Külekçi-Akyavuz, 2020). Öğrencilerde meydana gelen bu motivasyon düşüklügünü gidermek için okul yönetiminin de bazı çalışmalar yapmaları gerektiği düşünülmektedir. Zira yapılan bir çalışmada okul yöneticilerinin; öğretmenleri, öğrencileri ve velileri motivasyon etme rollerinin olduğu ve pandemi sürecinde bu rollerini gerçekleştirmek için büyük çabalar gösterdikleri sonucuna ulaşılmıştır (Külekçi Akyavuz ve Çakın, 2020).

Fen Bilgisi öğretmenleri uzaktan eğitim sürecinde öğrenciler ile Whatsapp, EBA ve Zoom gibi programlar aracılığıyla iletişim sağlamaya çalıştıklarını ifade etmişlerdir. Öğretmenlerin bu programları kullanmalarında, bu programların kolay ulaşılabilir, ekonomik ve kullanışlı olması gibi unsurlar etkili olduğu düşünülmektedir. Duban ve Şen (2020) tarafindan yapılan bir çalışmada uzaktan eğitim sürecinde öğretmen adaylarının ders takibini telefonda mesaj ve whatsapp aracılığıla yaptıkları belirlenmiştir. Ayrıca maddi imkânların yetersizliğinden dolayı tüm öğrencilerde akı1lı telefon veya tablet gibi araçların bulunmadığını ya da sınırlı sayıda olması nedeniyle çoğu öğrenciler ile iletişime geçmede sıkıntı yaşadıkları görülmüştür. Öğretmenler, uzaktan eğitim sürecinde öğretmen-veli arasındaki iletişimin etkili olmadığını dile getirmişlerdir. Diğer taraftan bazı velilerin ilgisizliğinin de öğrenciler ile iletişimi sağlamada sıkıntıya sebep olduğu düşünülmektedir. Bu sonuç Türk Eğitim Derneği'nin “Covıd-19 Sürecinde Eğitim Uzaktan Öğrenme, Sorunlar ve Çözüm Önerileri” raporu ile örtüşmektedir. Bu rapora göre; salgın sürecinde öğrencilerin öğrenme sürecinin daha etkili hâle getirilmesindeki en önemli unsurlardan birisi de evdeki teknolojik araçlardır. İnternet, bilgisayar, akıllı telefon gibi teknolojik araçları olan ve erişimi kolay olan öğrencilerin bu konuda diğer öğrencilere göre avantajlı olduğu açı bir şekilde söylenebilir (Arat ve Bakan, 2011). Uzaktan eğitimin sınırlı yönlerinden birisi de öğrencilerin daha önce öğretmenler ya da uzmanlar tarafindan hazırlanan içeriklere ulaşabilme imkânının olmamasıdır. Bu nedenle, her kesimden öğrencinin 
içeriklere ulaşmasının sağlanması ve on-line eğitim için kullanılacak iletişim araçlarının çeşitlendirilmesi büyük önem taşımaktadır (TEDMEM, 2020).

Araştırmaya katılan öğretmenler, Covid-19 pandemi sürecinin mesleki gelişimlerini olumlu etkilediğini belirtmişlerdir. Pandemi süreci nedeniyle uzaktan eğitime geçilmesi, öğretmenlerin teknoloji kullanımı zorunlu hale getirmiştir. Bunun sonucu olarak, teknolojik ürünleri kullanma konusunda kendilerini geliştirme firsatı doğurmuştur. Bu firsatın öğretmenlerin teknoloji okuryazar olmalarına olumlu katkı sağladığı düşünülmektedir. Bu sonuç çalışmaya katılan öğretmenler tarafından mesleki gelişimleri açısında olumlu bir durum olarak yorumlanmıştır. Ayrıca katılımcıların büyük kısmı, zor şartlar altında eğitim faaliyetlerini sürdürebildikleri için kendilerine olan güvenlerinin artığını ve bu süreçte kendilerini geliştirme firsatı bulduklarını ifade etmişlerdir. Diğer taraftan öğretmenler uzaktan eğitim ile yapılan derslerde daha az yorulduklarını belirtmișlerdir. $\mathrm{Bu}$ durumu, öğretmenler EBA'da öğretim materyallerine rahatlıkla ulaşılması ve evde derslerini yürüttükleri için zaman kaybının olmaması ile açıklamışlardır. Benzer bir çalışmada, Covid-19 sürecinde öğretmenlerin uzaktan eğitim aracılığıyla birçok teknolojik yazılım ve donanımı kullanmak zorunda kaldığı ve öğretmenlerin bu teknolojik araçların kullanımı konusunda kendilerini geliştirdikleri belirlenmiştir (Mulenga ve Marban, 2020). Yapılan başka bir çalışmada uzaktan eğitim sürecinde kullanılan iletişim teknolojilerinin kullanımına yönelik bir rehber klavuz hazırlanmış ve bu süreçte öğretmenlere yardımcı olunması amaçlanmıştır (United Nations Educational, Scientific and Cultural Organization [UNESCO], 2020). Buna karşın katılımcılar bu süreçte mesleki doyumlarının olumsuz olarak etkilendiğini ifade etmişlerdir. Katılımcıların olumsuz görüş beyan etmelerinde yüz yüze eğitimin olmamasının etkili olduğu düşünülmektedir. Yüz yüze eğitimin olmaması nedeniyle öğrenciler ile iletişim kurmada sıkıntılar yaşandığı düşünülmektedir. İleri süreçte yürütülecek araştırmalara yol göstermesi amacıyla araştırmada elde edilen sonuçlar ışığında aşağıda bazı öneriler sunulmuştur.

Bu araştırma, Doğu Anadolu Bölgesinde 10 Fen Bilgisi öğretmeni ile yürütülmüştür. Pandemi sürecinde karşılaşılan sorunlar hakkında daha kapsamlı bilgiye ulaşmak için farklı branşlardaki öğretmenlere yönelik farklı bölgelerde benzer araştırmalar gerçekleştirilebilir.

Pandemi sonrasında da öğretmenlerin uzaktan eğitimi yürütebilme faaliyetlerini güçlendirmek ve bilişim teknolojilerini kullanma becerilerini geliştirmek adına çeşitli kurs ve seminerler düzenlenebilir.

Eğitim sisteminin paydaşları olan öğretmen adayları, öğrenciler, okul yöneticileri ve aileler ile çalışmalar yürütülerek pandeminin olumlu ya da olumsuz etkileri boylamsal araştırmalar aracılığıyla ortaya koyulabilir.

Uzaktan eğitim yaklaşımına uygun olarak ders materyalleri hazırlanılabilir.

\section{Yazarların Katkı Oranı}

$\mathrm{Bu}$ makaleye birinci yazarın $\% 40$, ikinci yazarın $\% 30$, üçüncü yazarın ise $\% 30$ oranında katkıs1 vardır.

\section{Çıkar Çatışması}

$\mathrm{Bu}$ çalışmada çıkar çatışması oluşturacak bir husus yoktur. 


\section{Kaynaklar}

Angoletto, R. and Queiroz, V. C. (2020). COVID-19 and the challenges in education. The Centro de Estudos Sociedade e Tecnologia, 5(2), 1-12.

Arastaman, G., Öztürk-Fidan, İ. ve Fidan,T. (2018). Nitel araştırmada geçerlik ve güvenirlik: Kuramsal bir inceleme. YYÜ Ĕ̈itim Fakültesi Dergisi, 15(1), 37-75.

Arat, T. ve Bakan, Ö. (2011). Uzaktan eğitim ve uygulamaları. Selçuk Üniversitesi Sosyal Bilimler Meslek Yüksek Okulu Dergisi, 14(1-2), 363-374.

Arslan, Y. ve Şumuer, E. (2020). Covid-19 döneminde sanal sınıflarda öğretmenlerin karşılaştıkları sınıf yönetimi sorunları. Milli Ë̆itim Dergisi, 49(1), 201-230.

Baker, C., Wuest, J. and Stern, P. N. (1992). Methodslurring: The grounded theory/phenomenology example. Journal of Advanced Nursing, 17(11), 1355-1360.

Bakioğlu, B. ve Çevik, M. (2020). Covid-19 pandemisi sürecinde fen bilimleri öğretmenlerinin uzaktan eğitime ilişkin görüşleri. Turkish Studies, 15(4), 109-129.

Baltac1, A. (2019). Nitel araştırma süreci: Nitel bir araştırma nasıl yapılır?. Ahi Evran Üniversitesi Sosyal Bilimler Enstitüsü Dergisi, 5(2), 368-388.

Bayburtlu, Y. S. (2020). Covid-19 pandemi dönemi uzaktan eğitim sürecinde öğretmen görüşlerine göre Türkçe eğitimi. Turkish Studies, 15(4), 131-151.

Burke, J. and Dempsey, M. (2020). Covid-19 Practice in primary schools in Ireland report. https://www.into.ie/app/uploads/2020/04/COVID-19-Practice-in-Primary-Schools-Report-

1.pdf adresinden 02.02. 2021 tarihinde erişilmiştir.

Can, E. (2020). Coronavirüs (Covid-19) pandemisi ve pedagojik yansımaları: Türkiye'de açı ve uzaktan eğitim uygulamaları. Açıköğretim Uygulamaları ve Araştırmaları Dergisi, 6(2), 1153.

Çakın, M. ve Külekçi Akyavuz, E. (2020). Covid-19 süreci ve eğitime yansıması: Öğretmen görüşlerinin incelenmesi. International Journal of Social Sciences and Education Research, 6(2), 165-186.

Doğan, S. ve Koçak, E. (2020). EBA sistemi bağlamında uzaktan eğitim faaliyetleri üzerine bir inceleme. Ekonomi ve Sosyal Araştırmalar Dergisi, 7(14), 111-124.

Duban, N. ve Şen, F. G. (2020). Sınıf öğretmeni adaylarının Covid-19 pandemi sürecine ilişkin görüşleri. Turkish Studies, 15(4), 357-376.

Dünya Sağlık Örgütü (2020). WHO director-general's opening remarks at the media briefing on Covid-19. https://www.who.int/dg/speeches/detail/who-director-general-s-opening-remarks-atthe-media-briefing-on-Covid-19 adresinden 01.02.2021 tarihinde erişilmiştir.

Genç, M. F. ve Gümrükçüoğlu, S. (2020). Koronavirüs (Covid-19) sürecinde ilâhiyat fakültesi öğrencilerinin uzaktan eğitime bakışları. Turkish Studies, 15(4), 403-422.

Jasper, M. A. (1994). Issues in phenomenology for researchers of nursing. Journal of Advanced Nursing, 19, 309- 314. 
Karakuş, N., Ucuzsatar, N., Karacaoğlu, M. Ö., Esendemir, N. ve Bayraktar, D. (2020). Türkçe öğretmeni adaylarının uzaktan eğitime yönelik görüşleri. Rumelide Dil ve Edebiyat Araştırmaları Dergisi, 19, 220-241.

Külekçi-Akyavuz, E. ve Çakın, M. (2020). Covid-19 salgınının eğitime etkisi konusunda okul yöneticilerinin görüşleri. Turkish Studies, 15(4), 723-737.

Lee, S. A. (2020). Coronavirus anxiety scale: A brief mental health screener for Covid-19 related anxiety. Death Studies. 44(7), 393-401.

Lin, C. Y. (2020). Social reaction toward the 2019 novel coronavirus (Covid-19). Social Health Behaviour, 3(1), 1-2.

Milli Eğitim Bakanlığı. (2020). Ĕ̌itimin içeriği eğitim izleme raporu. https://www.egitimreformugirisimi.org/wp-content/uploads/2010/01/EIR_Egitimin_Icerigi.pdf adresinden 13.01.2021 tarihinden erişilmiştir.

Miles, M, B. and Huberman, A. M. (1994). Qualitative data analysis: An expanded Sourcebook. (2nd ed). Thousand Oaks, CA: Sage.

Mulenga, E. M. and Marban, J. M. (2020). Is Covid-19 the gateway for digital learning in mathematics education? Contemporary Educational Technology, 12(2), 1-11.

Sarıtaş, D. ve Kızkapan, O. (2020). Fen bilimleri öğretmen adaylarının kendi tasarladıkları öğretim materyallerine ilişkin görüş ve değerlendirmeleri. Ahi Evran Üniversitesi Sosyal Bilimler Enstitüsü Dergisi, 6(1), 1-18.

Türkiye Bilimler Akademisi (2020). Covid-19 pandemi değerlendirme raporu. Ankara: Türkiye Bilimler Akademisi Yayınları.

Türk Eğitim Derneği Düşünce Kuruluşu (2020). Covid-19 Sürecinde eğitim: Uzaktan öğrenme, sorunlar ve çözüm önerileri. https://tedmem.org/yayin/covid-19-surecinde-egitim-uzaktanogrenme-sorunlar-cozum-onerileri adresinden 15.01.2021 tarihinde erişilmiştir.

United Nations Educational, Scientific and Cultural Organization. (2020). How to keep engaged remotely with your students in the context of the COVID-19 Crisis: Tips for Teachers. https://en.unesco.org/news/resources-parents-and-teachers-motivating-supporting-childrenduring-remote-learning adresinden 15.01.2021 tarihinde erişilmiştir.

Uşun, S. (2006). Uzaktan eğitim. Ankara: Nobel Yayıncılık.

Yamamoto, G. T. ve Altun, D. (2020). Coronavirüs ve çevrimiçi (on-line) eğitimin önlenemeyen yükselişi. Üniversite Araştırmaları Dergisi, 3(1),25-34.

Yıldırım, A. ve Şimşek, H. (2013). Sosyal bilimlerde nitel araştırma yöntemleri. Ankara: Seçkin Yayınc1lı. 


\section{Extended Abstract}

\section{Introduction}

Covid-19 pandemic has caused around one-billion students to become distant from learning environments around the world. In order to minimise the negative effects of the pandemic upon learning environments, countries tried to close this mandatory gap through distance learning environments. With quarantine and the shutdown of education institutions the entire world has entered into an unexpected process. Learning was tried to be resumed and supported out from homes through digital platforms. This naturally brought up distance learning or in other words the online education (Genç and Gümrükçüoğlu, 2020). Today, distance education, born as an alternative to formal education, is an education system in which technology is integrated without the limitations of both time and space (Uşun, 2006; Yamamoto and Altun, 2020). For many years various language courses, occupational and career certificate programs and the open education model within the high-school and university system have been conducted as a part of the distance education in our country. In this regard, Turkey is no stranger to the distance education system. Number of students in distance learning is increasing each day. The distance education model applied in the certain departments of public schools is an education system that is gradually developing and becoming widespread. Distance learning approach has begun to acquire a wider range of application due to the Coronavirus precautions. With the justification that it may be convenient for students to have lessons in a physical environment; this system has enabled secondary education and universities that offer classical education to spread distance education even more for precautionary purposes (Genç and Gümrükçüoğlu, 2020).

It can be said that studies on this pandemic are mostly in the field of health and there are fewer studies in the field of education. It has been witnessed that, during the pandemic period, studies concerning the problems faced by Science teachers on the education environment were very few in numbers especially within the field literature. It can be said that one of the most difficult education stakeholders during the pandemic process were teachers. Science teachers are thought to be the most effected group within these teachers. Laboratories are needed as various subjects are thought through experiments in Science classes. It has been believed that, while experiments are difficult to be conducted by distance education approach, the most effected personnel from this process are Science teachers. On the other hand, this study is important when it is considered that determining the problems faced with Science teachers during the pandemic process will guide teachers in different branches and shed light on future studies. Thus, the purpose of this study is to determine the achievements and problems of the Science teachers during the Covid-19 pandemic distance education process.

\section{Method}

This study has been conducted by fact science (phenomenology) pattern as one of the qualitative research methods. Fact science is a method that focuses on the evaluation of lived experiences (Jasper, 1994). Participators consist from 10 Science teachers stationed at Van province during the 2020-2021 education-learning calendar. All of the participants are stationed at public schools. In determining the participants, easy accessible sample, from the purposive sample methods, was used. Data were gathered through semi-constructed interview form. In order to determine the problems faced by Science teachers in the learning environment during the Covid-19 pandemic process, a semi-structured interview form was created by researchers.

Data were resolved by narrative and content analysis method. Interviews with participants were put into prose by researchers. Data reduction was performed on the raw data that had been put into prose. First, from the data; codes, themes and categories were extracted by three different researches including the researchers themselves. Second, three researchers determined the rate of harmony on the extracted cod and theme. In the calculation of this rate of harmony, reliability formula 
which was recommended by Miles and Huberman (1994) was used. In the research, the harmony reliability was determined as $84 \%$ between coders. This value shows that it is reliable for the coding for qualitative studies (Miles and Huberman, 1994).

\section{Findings}

When table 8 was examined, it can be seen that, the pandemic period had a positive effect on the participants' use of technology in the field education. Science teachers stated that, during the pandemic period; concepts such as increase in the beginning to use on-line platforms ( $\mathrm{f}=8)$, increase in discovering different programs $(\mathrm{f}=8)$ and increase in the use of technology $(\mathrm{f}=8)$ has become an important part of their lives. Teachers' comments are on this subject are given below.

Science teachers have stated that, Covid-19 pandemic has positive effects on their occupational developments. As teachers were able to continue the education process under difficult conditions, they stated that; their self-confidence was advanced ( $f=5)$, found opportunities for selfdevelopment $(\mathrm{f}=4)$, connecting with students upon a different field $(\mathrm{f}=2)$ and became less tried during the on-line education process $(\mathrm{f}=2)$. Two of the teachers' stated that the Covid-19 pandemic had negative effects on their occupational development. Teachers supported this negative commentary with codes of everybody using different applications ( $\mathrm{f}=2$ ), suffering from information athrophy during distance education process ( $\mathrm{f}=2$ ), increase in the sense of longing for school ( $\mathrm{f}=2$ ), difficulty in communicating with students during the distance education period $(\mathrm{f}=1)$ and sense of emptiness $(\mathrm{f}=1)$. Two teachers stated that the pandemic period had both positive and negative effects on their occupational developments. Teachers' explained this with incapability in class control, selfdevelopment opportunity, lack of face-to-face teaching and living a different experience.

\section{Conclusion, Discussion and Recommendations}

Science teachers stated that the Covid-19 pandemic period had positive effects on their occupational developments. Due to the pandemic, teachers have shifted to distance education. Teachers' use of technology has become mandatory during this educational process. This situation has given teachers' the opportunity to improve themselves in using technology products that they had to use through distance education. This opportunity had positive effects for becoming technological literacy. This result was interpreted by teachers participated to this research as a positive circumstance in regard to their occupational developments. Apart from this, large part of the participants stated that due to the continuation of education under dire conditions, their self-confidence was grown and they found an opportunity for self-development during this process. Teachers' also stated that, they became less tired with classes performed through distance education. Teachers' explained this by easy access to the teaching materials in Education Information Network and no waste of time since they conducted their lessons from home. In a research done on this subject, during the Covid-19 process, teachers had to use many technological software and hardware through distance education. In this process, it has been concluded that, teachers improved themselves in using these technological devices (Mulenga and Marban, 2020). In another research a guide had been compiled on the utilisation of communication technologies in use and aimed at aiding the teachers in this process (United Nations Educational, Scientific and Cultural Organization [UNESCO], 2020). Despite to this participants have stated that their occupational fulfilment has suffered negatively. Lack of face-to-face teaching is thought to be the reason for the negative opinions. Because of the lack of face-to-face teaching there are problems in communicating with students. In order to guide further studies in this process, some recommendations are made in the light of the results acquired in this present research. After the pandemic, it is recommended to organise various courses and seminars in order to strengthen the distance education activities of teachers during the pandemic process and to improve their skills in using information technologies. 